\title{
Development of Purchasing Module for Agriculture E-Commerce using Dynamic System Development Model
}

\author{
Rosa Delima ${ }^{1}$ \\ Informatics Department \\ Duta Wacana Christian University \\ Yogyakarta, Indonesia
}

\author{
Halim Budi Santoso ${ }^{2}$, Novan Andriyanto ${ }^{3}$, Argo \\ Wibowo $^{4}$ \\ Information System Department \\ Duta Wacana Christian University \\ Yogyakarta, Indonesia
}

\begin{abstract}
Trading model has been changing since the vast implementation of Information and Communication Technology in every sector. This model is known as e-Commerce. Unlikely, there is still limited company which specifically trades agriculture product. Agriculture e-Commerce is known as a platform to buy and sell some agriculture products. Agriculture e-commerce has important role to support economic development and market expansion for farmers in particular and people in rural areas in general. There is still limited access and provider which buy and sell agriculture product to farmer and its farmer representative. Therefore, this research develops specific agriculture e-commerce. There are two main modules for agriculture e-commerce, purchasing and buying module. On this article, we acknowledge to develop the first module, which is purchasing module. Purchasing module was developed using Dynamic System Development Method (DSDM). Development phase includes feasibility study, business study, functional model iteration, and design and build model iteration. At the end of the phase, testing is conducted. The result of this study is the prototype of agriculture e-Commerce product with predefined functions. Purchasing module of the system depicts the opportunity for farmer to buy the tools and materials. This system has two main functions: purchasing system management and reporting management. System testing also was conducted to test the system.
\end{abstract}

Keywords-Agricultural e-commerce; dynamic system development method; DSDM; purchase module

\section{INTRODUCTION}

Purchasing and Selling are two main processes of trading business, goods and services. In the era of industry revolution 4.0 , there is a change in the trading business model. In the conventional model, buyer and seller meet directly face to face. Nowadays, there is a shifting to become trading model based on Information and Communication Technology (ICT). This trading model is known as e-commerce. E-Commerce is a trading model, including purchasing, selling, and exchanging goods, services, and information through computer network and internet [1].

E-Commerce business model evolves rapidly in some countries in the world. This business model offers some advantages, either for seller and buyer. Two e-Commerce advantages are: (1) e-Commerce is able to decrease company operational costs; (2) Buyers can save time in shopping and get flexibility at certain levels in shopping [2]. However, eCommerce business model have not reached agriculture sector, especially in developing countries such as Indonesia. There are some e-Commerce companies, such as Lazada, Tokopedia, Elevania, and OLX. Among those e-Commerce companies, there is none of e-Commerce companies which focus on selling agriculture product. Thus, in this research, researcher developed an e-Commerce system which sells agriculture tools, materials, and products specifically.

System development uses Dynamic System Development Model (DSDM). The usage of this method is based on the advantages of DSDM as agile development models [3]. This model tries to look for equilibrium process so the model is able to work in dynamic environment. Dynamic environment usually involves requirement changes. This model suppresses the control mechanism in customer feedback to ensure a high level of customer satisfaction [4].

Agriculture e-Commerce system contains two main module, purchasing module and selling module. This article discusses development of purchasing module as part of Agriculture e-Commerce system. Purchasing module was developed intended for buyer of agriculture products offered. This system is developed using PHP and HTML5 and database engine MySQL. Purchasing module user are buyers. This module has some functions, including goods selection, discussion with sellers, and buying directly using system.

\section{LITERATURE REVIEW}

\section{A. Dynamic System Development Metohod (DSDM)}

Dynamic System Development Method is one of agile methodology that is used to develop software. Dynamic System Development Method (DSDM) is a method that has been developed based on software development success experience. This method is an improvement method for Rapid Application Development (RAD). This method is flexible and practical for software project management [5][6][7].

DSDM has 4 basic philosophies: (1) Development process is a team work. This process is a combination between customer knowledge about business process and business requirement and IT staff professional; (2) good quality 
demands suitability with good technical skills; (3) Development process can be incremental means that not everything can be done; and (4) The diminution of the law of increasing returns means that resources must be used to develop features that are most valuable to the business [5].

DSDM has 9 important principles: (1) User active participation is an important part and needed for system development; (2) Development team should have authority to take decision; (3) Focusing on product completion periodically; (4) Suitability with business is a product acceptance criteria; (5) Development is an iterative and mandatory incremental process; (6) All changes in the development process must be reversible, which means that changes do not affect the cycle, system, and environment; (7) It is needed to define system "high level"; (8) System testing is a life cycle integrated part; and (9) Collaborative and Cooperative Approach is used in this method [8].

DSDM system development is called "The three pizzas and a cheese". The three pizzas are DSDM three main stages, Functional Model Iteration, Design and Build Iteration, and Implementation. Meanwhile, "a cheese" is 2 initial stages software development process, Feasibility and Business Study. The DSDM Software Development Process can be seen in Fig.1.

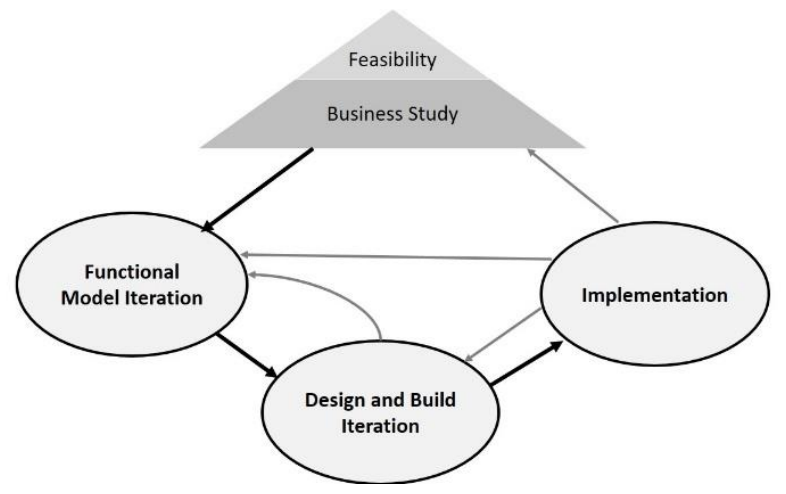

Fig. 1. Dynamic System Development Method.

Figure 1 shows Dynamic System Development Method diagram. It is shown that there are 3 main stages and 2 initial stages for software development. 2 Initial Stages are Feasibility study and Business study. Those 2 initial stages should be conducted before the main stages. 3 main stages are Functional Model Iteration, Design and build iteration, and Implementation. Functional Model Iteration consists of 4 main sub stages: (1) Create functional prototype; (2) Agree schedule; (3) Identify functional prototype; and (4) Review prototype. Design and build iteration is the next stage after Functional Model Iteration and consists of four sub-stages: (1) Identify design prototypes; (2) Agree schedule; (3) Create design prototypes; (4) Review design prototypes. And the last stages is the implementation which has 4 sub-stages: (1) Review Business; (2) User approved and user guidelines; (3) Train user; and (4) Implement.

\section{B. Agriculture e-Commerce}

Agriculture e-Commerce is an e-Commerce implementation for agriculture sector. In particular, agriculture
e-Commerce involves internet usage, including mobile phone to provide information and bring together supply and demand in Agriculture sector. In the farmer's point of view, eCommerce is selling and buying activity for agriculture product by using internet [9].

Agriculture e-Commerce is important to be developed since this system is needed to: 1) grow economic development in agriculture sector; 2) accelerate agriculture information flow; 3) spread market for agriculture sector; 4) promote industrialization process for agriculture [10]. There is some models to implement agriculture e-Commerce, including Business to Business (B2B), Farmer to Customer (F2C), Farmer To Association To Business (F2A2B), Online to Offline (O2O), Business to Business to Customer (B2B2C), Peasants to Customer to Business (P2C2B), and Peasants to Government to Business (P2G2B) [9][10]

China and India as agricultural country have started to develop agriculture e-Commerce. There is similarity for two eCommerce business model. China and India involves ebusiness farmers, organization, and company as an integrated agriculture e-Commerce [11]. Therefore, there is a different in its implementation: 1) initiative e-Commerce implementation in India is aimed to cut production and buying cost, while in China is to increase farmer's revenue; 2) Agriculture eCommerce business model in India to facilitate farmer to buy land and daily need through e-business mobile. On the other hand, China agriculture e-Commerce business model to ensure farmer's comfortable to sell agriculture product using PC and internet network; 3) Government has direct and special role in India, while China government only provides macroeconomic guidance or indirect regulation through finance, tax, law, and indirect participation in the market; and 4) Agriculture eCommerce in Indonesia focuses on cheap goods and similar form of technology and electronics. Meanwhile, China Agriculture e-Commerce supports good quality products and more mature and multiform business model platforms [11]

During the development and implementation of agriculture e-Commerce, there are some problems that should be faced: 1) Low level of agriculture informatization; 2) Rural society's knowledge to use e-Commerce is still limited; 3) Less knowledge to optimize e-Commerce benefit; 4) Incomplete eCommerce environment; 5) Various agriculture product characteristics; 6) Limited internet access; and 7) Agriculture practitioner lack of skill in using technology [9]. Thus, there are some considerations to develop and implement agriculture e-Commerce: 1) Integration of required information resources; 2) e-Commerce should focus on area development; 3) The need of strengthening the logistics and distribution system; 4) The need of strategy to boost farmer's and customer's profit [10]. Agriculture e-Commerce is important to raise rural society economic development. Perception, awareness, and obstacles are the most important things to implement agriculture eCommerce. Perception relates with obstacles, while awareness relates with perception and obstacles. Farmer awareness and infrastructure support play important role in successful implementation of agriculture e-Commerce [12].

Institute of Research and Community Service Duta Wacana Christian University (DWCU) and Informatic Department DWCU. 


\section{RESEARCH METODOLOGY}

This study use Dynamic System Development Method (DSDM). There are 5 main stages in development process of purchasing module: 1) feasibility study; 2) business study; 3 ) functional model iteration; 4) design and build iteration; and 5) implementation. This study is only up to the fourth stage, namely design and built iteration.

\section{A. Feasibility Study}

This is the first stage in developing agriculture eCommerce. In this stage, it is identified some problems that for research background. There is no e-Commerce that particularly provides agriculture tools, materials, and product. This system has important roles in expanding the market for trading agricultural product that will provide bargaining power for farmers and actors involved in agricultural business.

Feasibility study also does some implementation eligibility assessment from resources availability, including development team and funding. Development team for agriculture eCommerce consists of 6 persons as analyst, designer, and code implementation. Other while, this project is funded by Institute of Research and Community Service Duta Wacana Christian University (DWCU) and Informatics Department DWCU. Based on resources availability, agriculture e-commerce is considered worthy to be executed.

\section{B. Business Study}

Business study is the second stage to analyze business process relate to the system to be developed. Development of agriculture e-commerce is a stage that is already planned for Integrated Agriculture Information System (IAIS). IAIS is a study project has been conducting since 2015 and will continue until 2022. Agriculture e-commerce development is stated in developed IAIS blueprint [13][14][15]. Agriculture eCommerce development in accordance with IAIS business motivation: development of architecture and application for IAIS. This goal has 3 objectives: 1) Blueprint strategy for system development; 2) Availability of IT infrastructure; 3) Development of Agriculture Information Systems and Knowledge Based Systems [15].

\section{Functional Model Iteration}

Functional Model Iteration is an iterative stage that is conducted to do modelling for system functionalities. Specifically, this step is to model functionalities in purchasing module of agriculture e-Commerce. There are two main functions: 1) Purchasing transaction management; 2) Reporting management. Those two functions are mapped and shown in table 1 below:

TABLE I. MODUL FUNCTIONALITY MAPPING

\begin{tabular}{|l|l|}
\hline Functional Model & Module \\
\hline \multirow{4}{*}{$\begin{array}{l}\text { Purchasing Transaction } \\
\text { Management }\end{array}$} & Buyer Login \\
\cline { 2 - 2 } & Material, Tools, and Product searching \\
\cline { 2 - 2 } & Material, Tools, and Product Purchasing \\
\cline { 2 - 2 } & Payment \\
\cline { 2 - 2 } & Payment Verification \\
\hline \multirow{2}{*}{ Reporting Management } & Seller Reporting \\
\cline { 2 - 2 } & Admin Reporting \\
\hline
\end{tabular}

\section{Design and Build Iteration}

This is the fourth stage in development process. Purchasing module design includes use case diagram design, database design using ER Diagram, activity diagram, sequence diagram, and interface design.

Use case diagram is used to give some explanations of each user's role and functionalities. Purchasing module has two main actors: Buyer and Administrator. Use case diagram is show in figure 2 below.

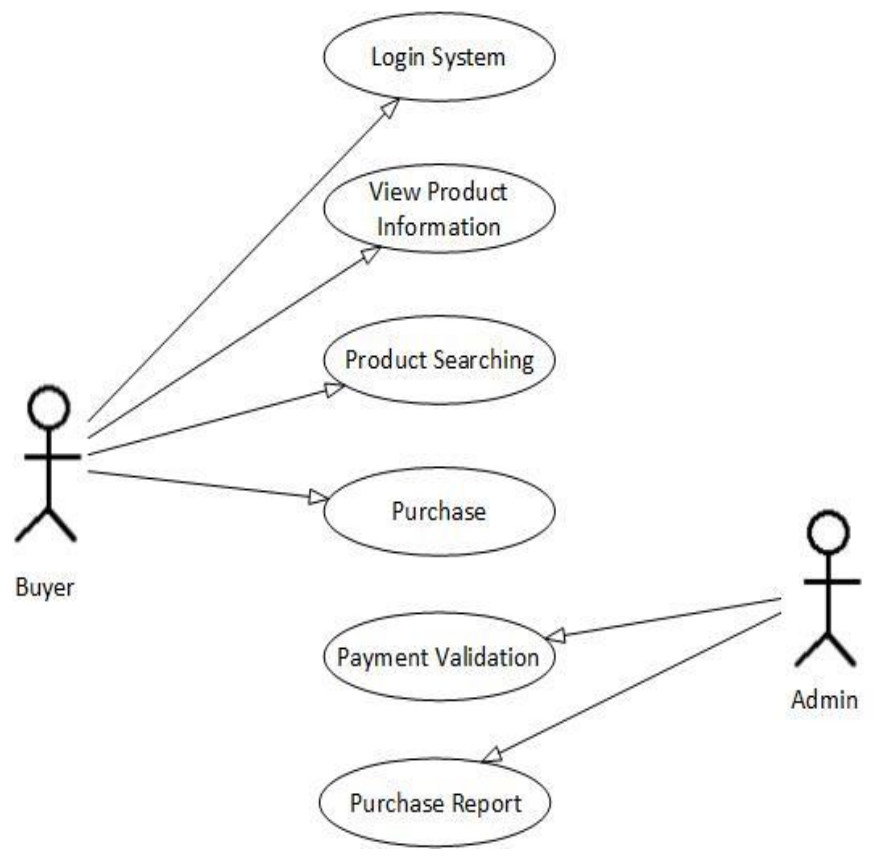

Fig. 2. Purchasing Module Use Case Diagram.

Figure 2 shows that there are two main actors: buyer and system administrator. Each user has its use cases. Buyer is able to 1) login to system; 2) material, tool, and product searching; 3) see information related to the product offered; 4) buying agricultural material, tools, and product; and 5) processing payment. On the other hand, system administrator is able to validating payment and generates purchasing report.

Database design of purchasing module was designed using Entity Relationship Diagram. This process uses Logical Data Modelling. There are 8 steps in the modelling: 1) identify main entities; 2) depiction of entity relationship; 3) defining primary and secondary key; 4) defining foreign key; 5) business rules definition; 6) non-key attribute addition; 7) validating normalization rules; 8 ) data dictionary creation. There are 12 entities in e-commerce database. The followings are relation scheme:

- Master_detail_user(ID_User Primary Key),

- Master_kategori(ID_Kategori Primary Key),

- Master_user_kat(ID_kategori, ID_user Both are Foreign Key from table master_kategori and master_detail_user),

- Master_user(ID_User Primary Key), 
- Master_Produk_Tani(ID_Produk Primary Key),

- Master_Spesies_tanaman(ID_Spesies Primary Key),

- Master_Kategori_Produk(ID_Kategori Foreign Key from table Master_kategori),

- Master_alat_tani(Id_Alat Primary Key, ID_Kategori Foreign Key from master_kategori),

- Master_bahan_pertanian(ID_Bahan Primary Key, ID_Kategori Foreign Key from table Master_kategori),

- Trans_harga_produk(ID_Produk Foreign Key from Master_produk_tani, ID_User Foreign Key from Master_detail_user),

- Trans_permintaan(ID_Permintaan Primary Key, ID_User Foreign Key from Master_detail_user, ID_Penawaran Foreign Key),

- Trans_penawaran_prod_tani(ID_Penawaran Foreign Key, ID_User Foreign Key from Master_detail_user). 3 .

Complete figure of Database design can be seen in Figure

The next modelling is activity diagram. There are three main processes: 1) login process; 2) purchasing process; and 3) report generating process. Activity diagram of each process can be seen in fig. $3-5$.

Figure 4-5 shows activity diagram of each main activities. Fig. 4 shows activity for login process. User should have an account to login. If there is no account, user should register it through the website. Administrator will verify new user registration. An email is able only once to be used to register the new user and will be active in a day.

Figure 5 shows activity diagram to order agriculture tools, materials, and product. To order, user should have an account. User should pay the order to website administrator. System administrator will verify the payment. If it is success, system administrator will forward the order to the seller and change the status to indicate that the order is already paid. Seller will sent the order to the buyer if it is ready.

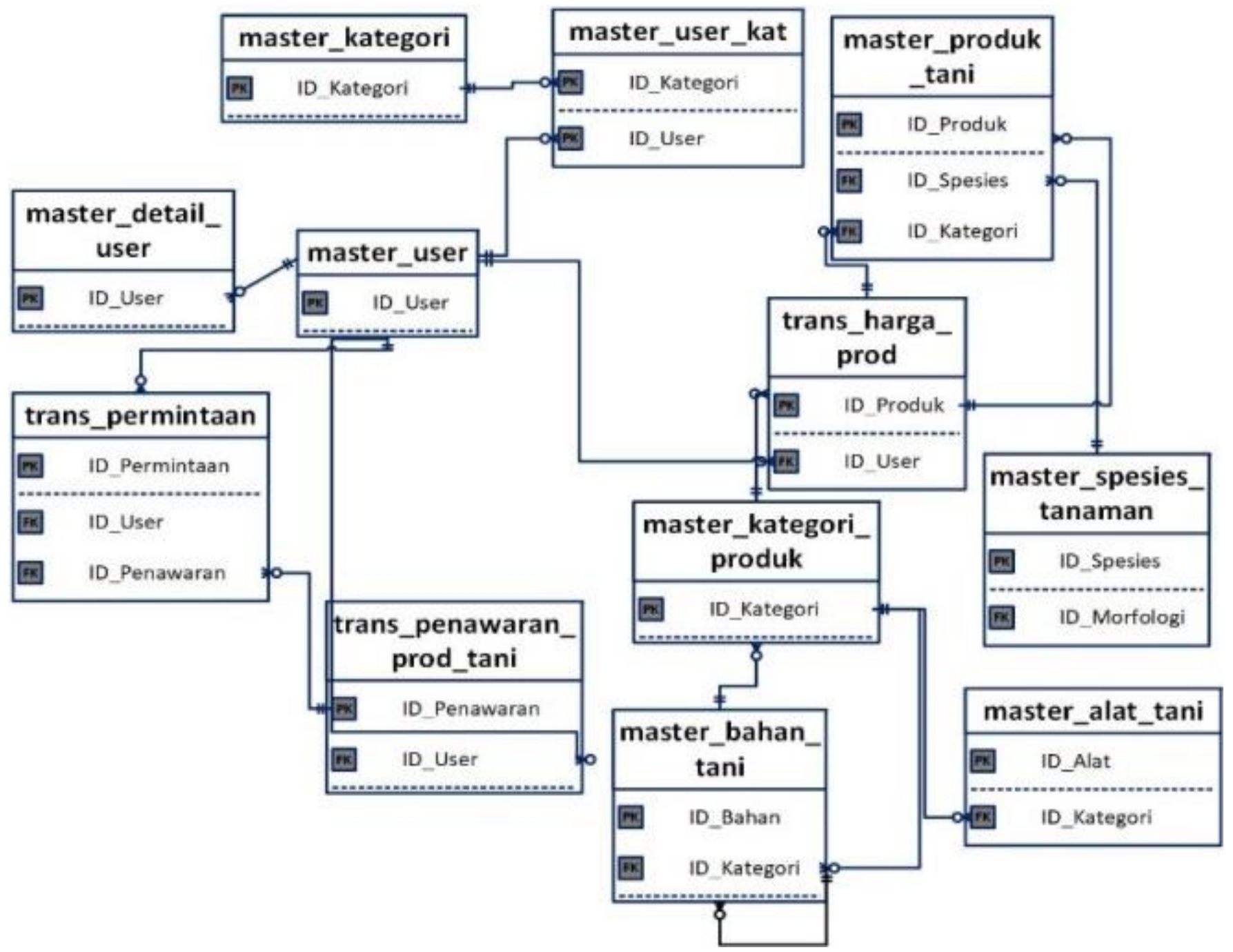

Fig. 3. Entity Relationship Diagram Purchasing Module. 


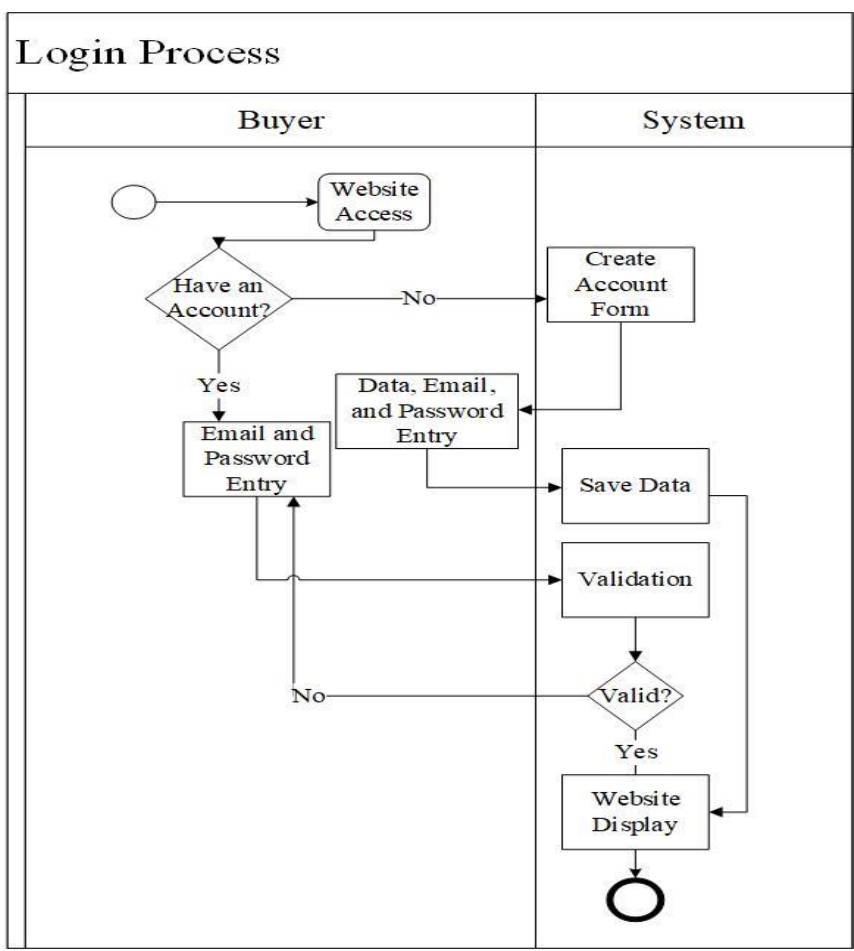

Fig. 4. Activity Diagram Login Process.

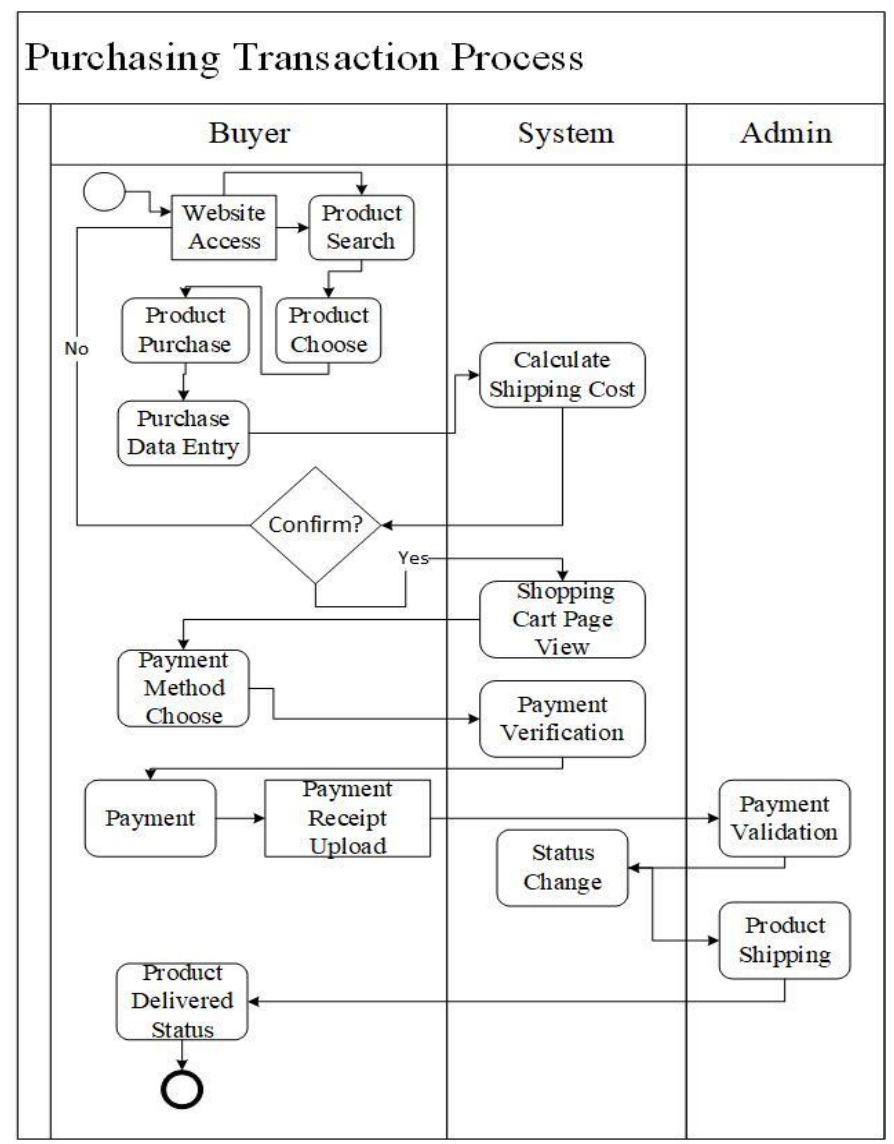

Fig. 5. Activity Diagram Purchasing Transaction.

\section{Report Generating Process}

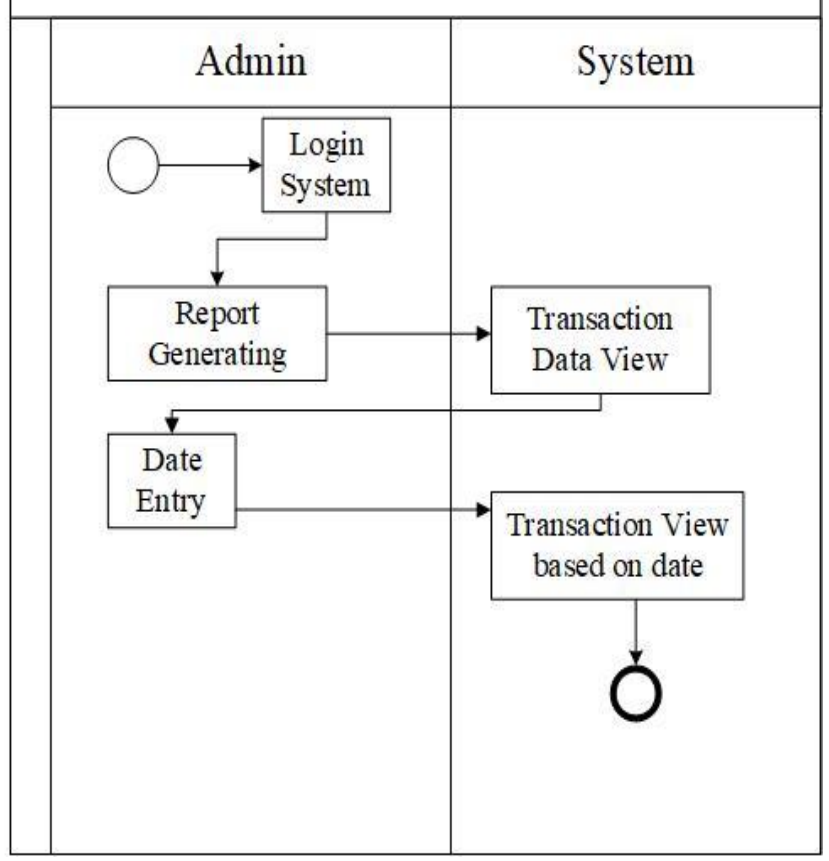

Fig. 6. Activity Diagram Report Generating.

Figure 6, shows activity diagram to manage report. User should determine and enter the specific date for report. The system will generate the desired report.

Sequence diagram is the diagram to describe the interaction between object and system. There are 6 sequence diagrams for purchase module: 1) user login sequence diagram; 2) see item information; 3) search specific item; 4) purchase item; 5) payment verification; and 6) generate report. Sequence diagram of six main activities are shown in fig. $6-11$.

The first sequence diagram is user login (fig. 7). This diagram shows the process of login user. User input id and password, after that system will check user id and password on user data. If data conform then user will be directed to purchasing page. In purchasing page, user can search product as shown in fig. 8. User can click the product to see information detail. Sequence diagram for viewing product detail can be seen in fig. 9. The steps that user should do for purchasing can be seen in fig. 10. The admin payment verification process can be seen in fig. 11. User admin can perform report by following the steps in the fig. 12 .

After completing the database and process design for purchasing module, the next step is to design the user interface for purchasing module. There are 11 user interface design for purchasing module in agriculture e-Commerce. Those are home, user login, user registration, product detail, shopping transaction, shopping cart, payment form, user profile detail, admin dashboard page, payment verification, and reporting page. 


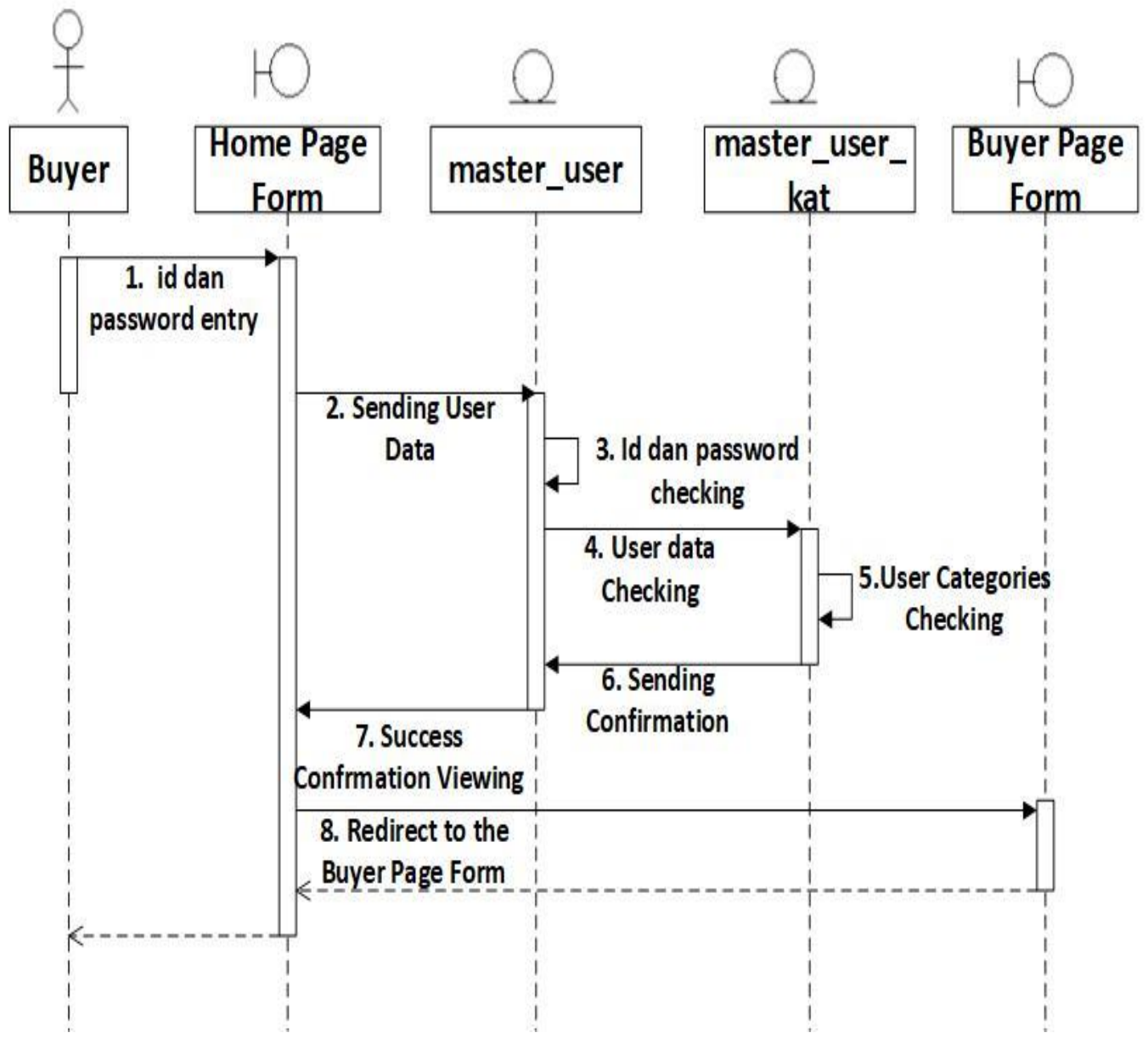

Fig. 7. Sequence Diagram User Login.

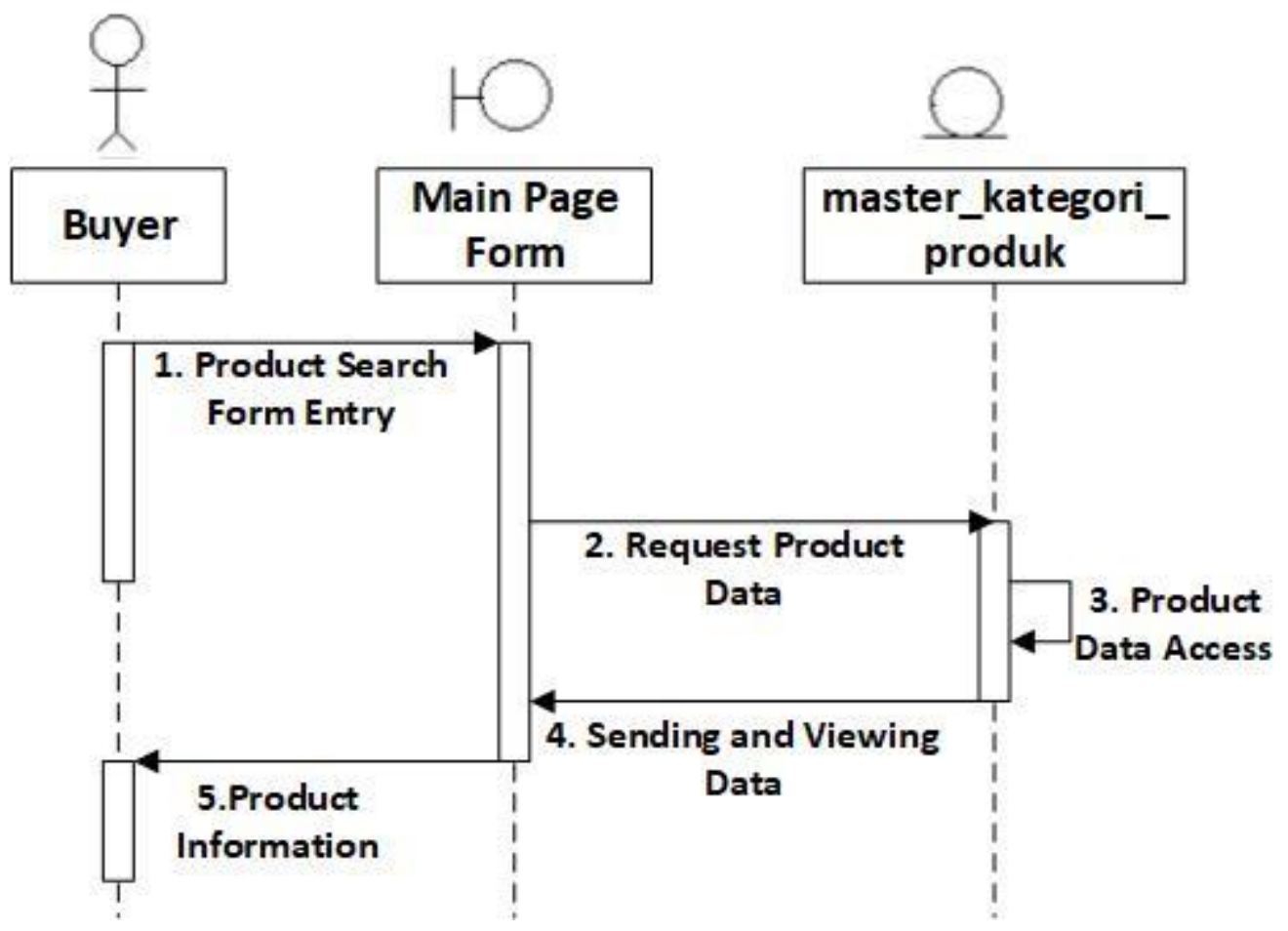

Fig. 8. Sequence Diagram Item Searching. 


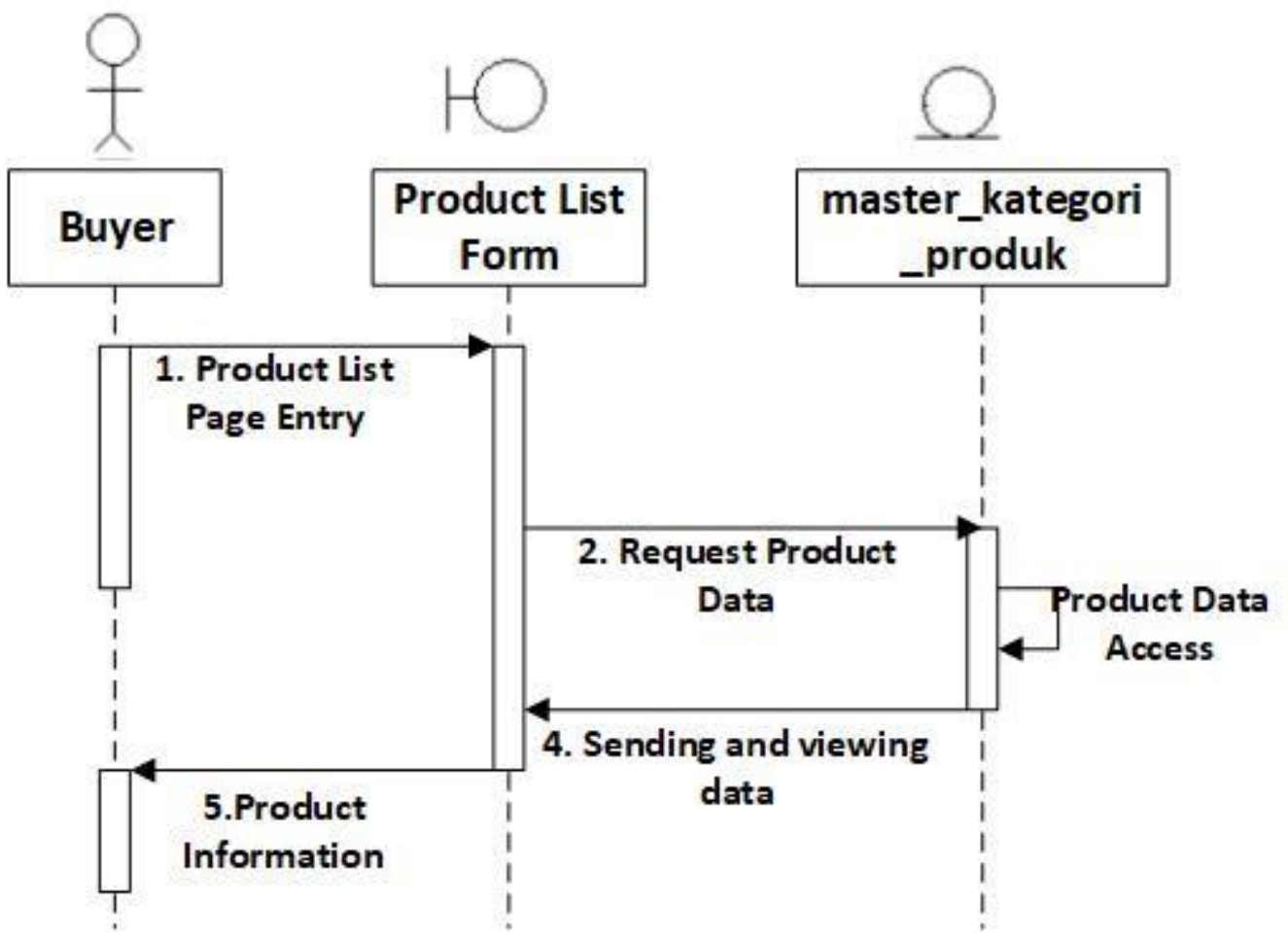

Fig. 9. Sequence Diagram Viewing Item Information.

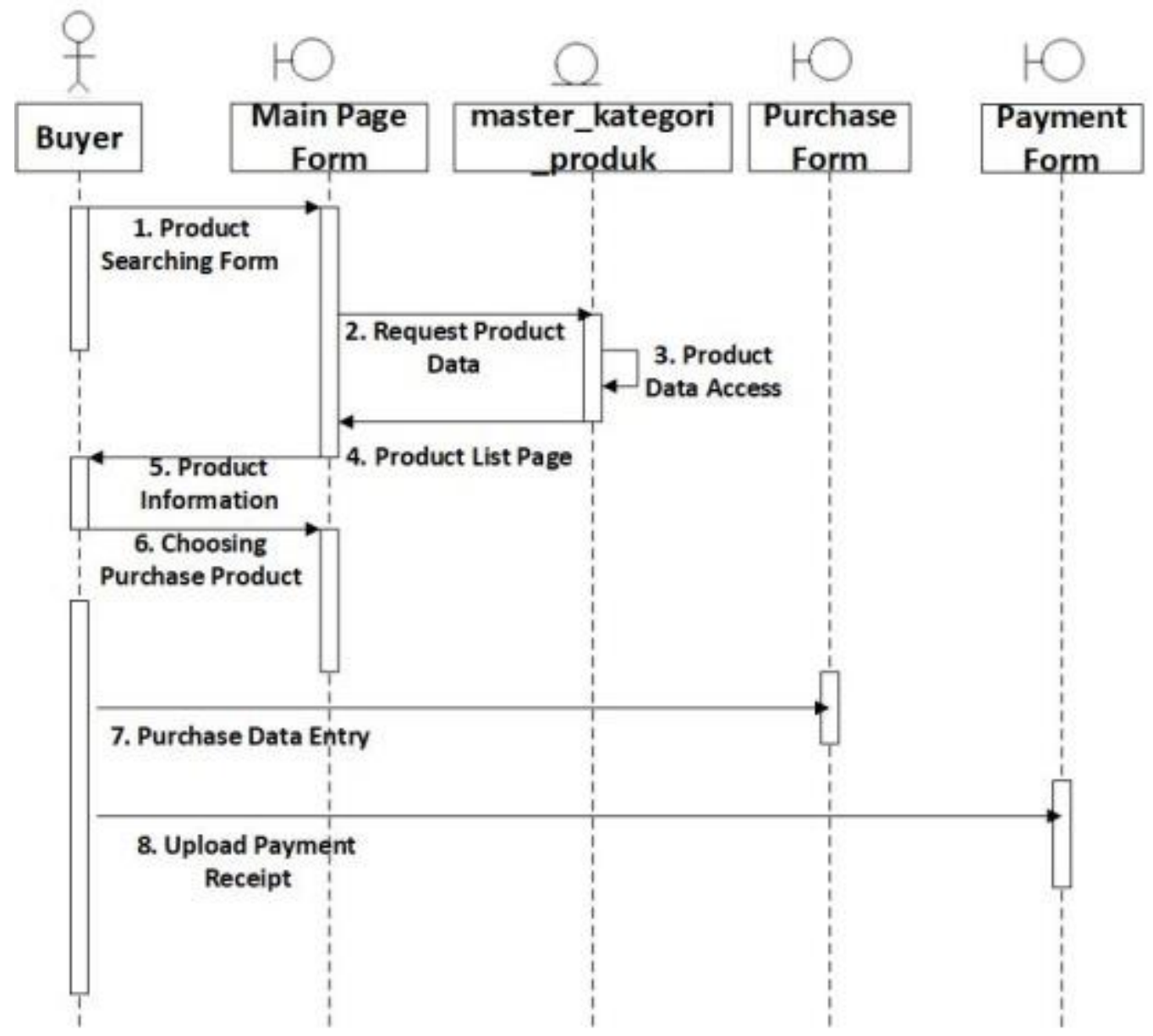

Fig. 10. Sequence Diagram Purchasing Item. 


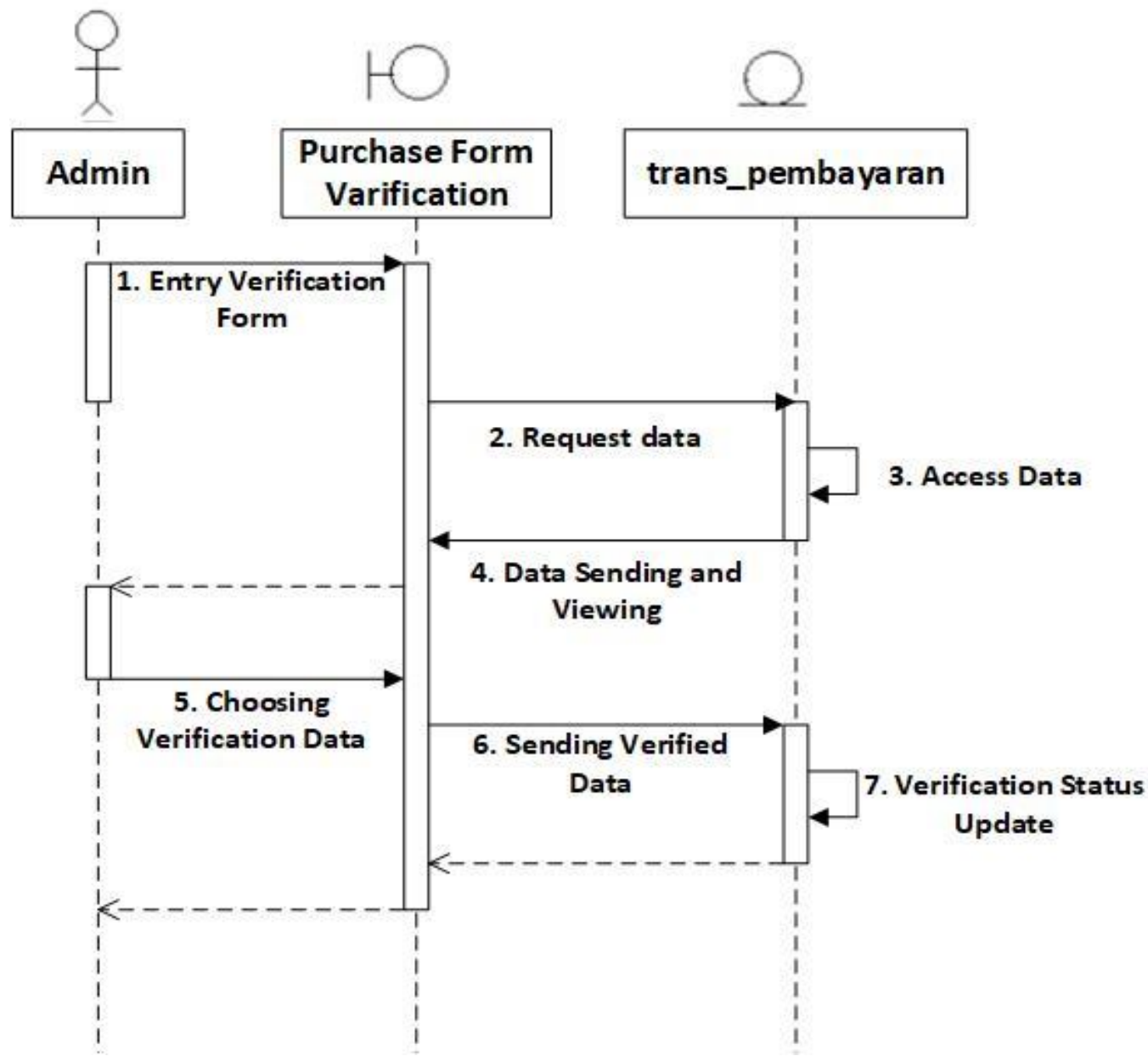

Fig. 11. Sequence Diagram Payment Verification.

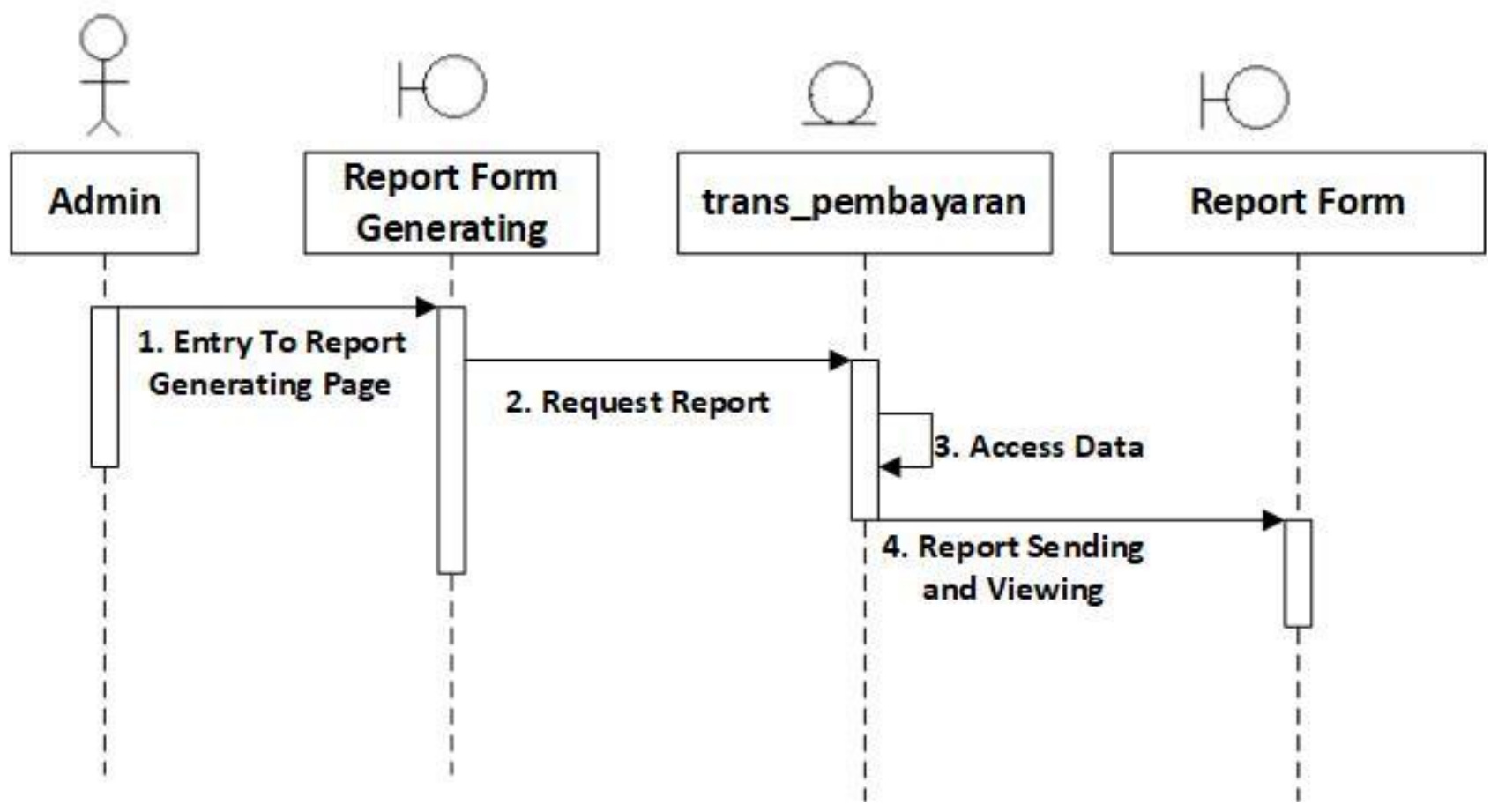

Fig. 12. Sequence Diagram Report Generating. 


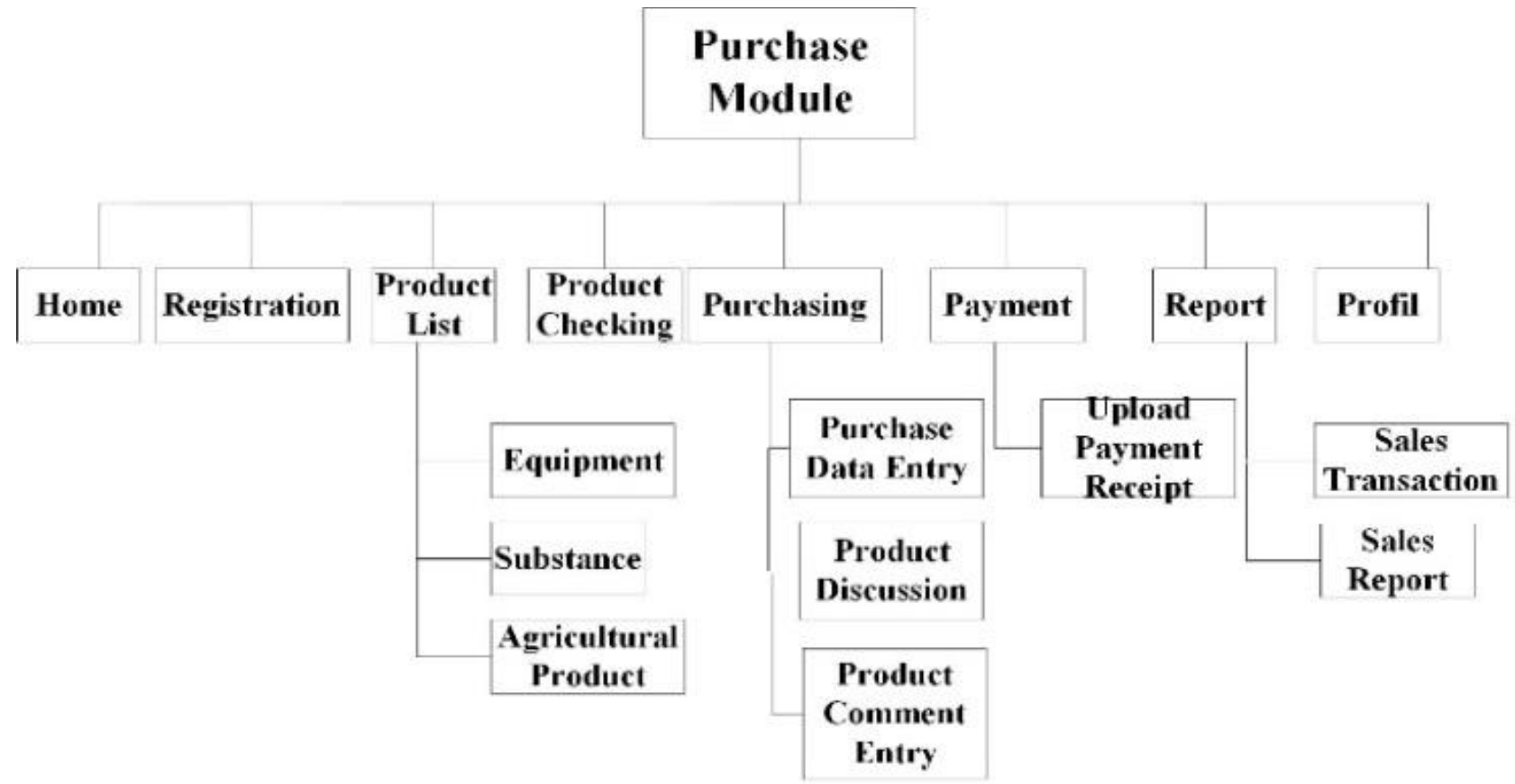

Fig. 13. Agriculture e-Commerce Purchasing Module Site Map.

\section{IMPLEMENTATION AND ANALYSIS}

\section{A. Purchasing Module Implementation}

Agriculture e-Commerce purchasing module has this following sitemap, as shown in fig. 12.

Figure 13 shows purchasing module site map. Purchasing module has 8 main menu: home, registration, product information, product detail, purchasing module, payment, reporting, and user profile. Some of those menus has sub menu which bring user to get more detail information.

Figure 14 shows user login page for user authentication. User should have an account to login. If the user does not have an account, user should register it and the system administrator will verify the registration.

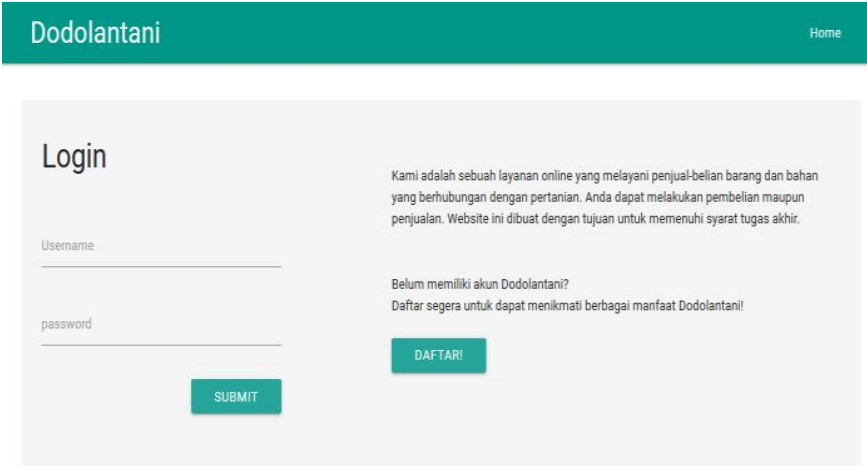

8.72713002:

Fig. 14. User Login Page.
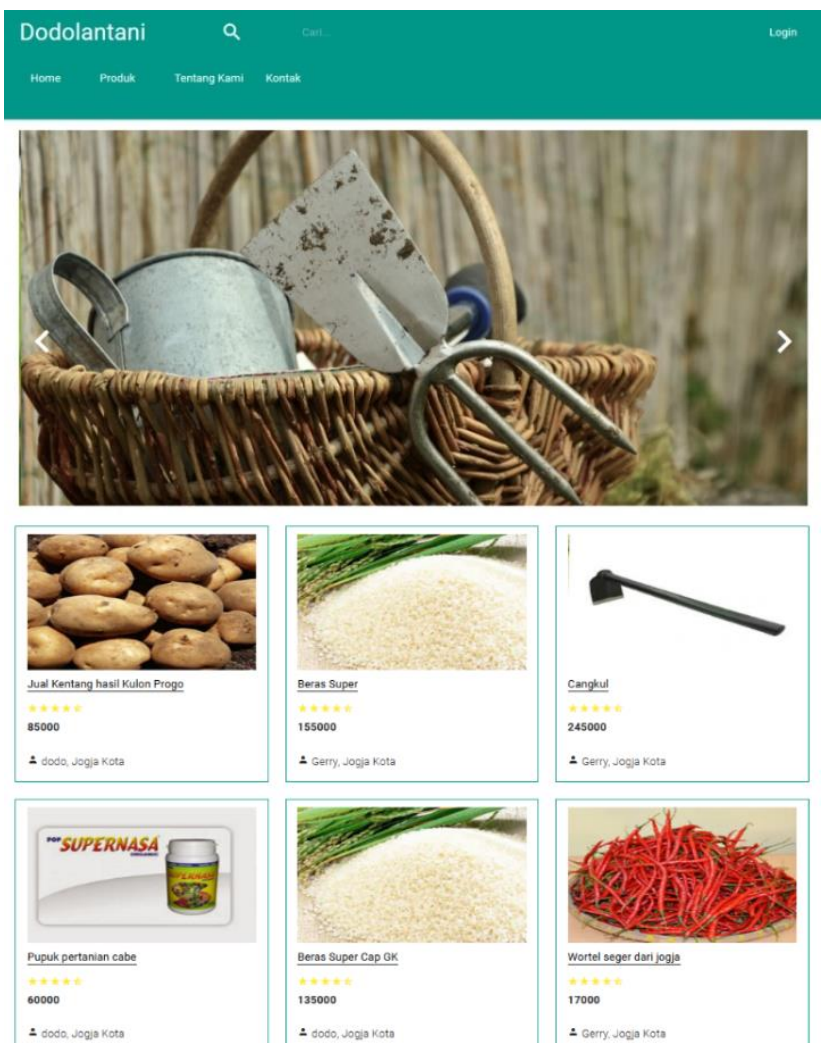

Fig. 15. Product Page.

Figure 15 shows the product page information. This page gives the product information, price, and the seller. User is able to see the detail information by clicking the product picture or product name. 

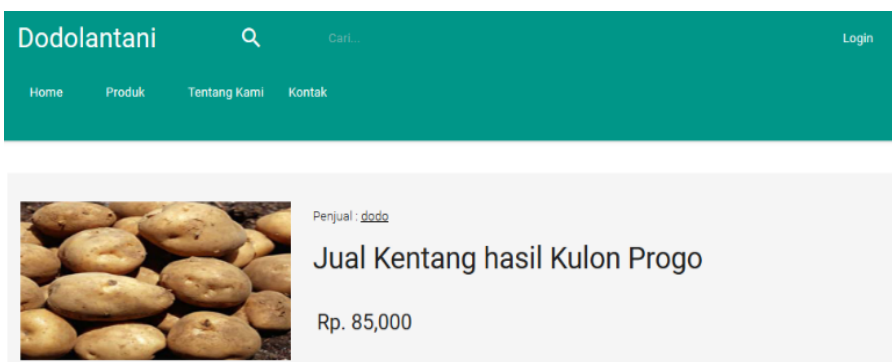

Jual Kentang hasil Kulon Progo Rp. 85,000

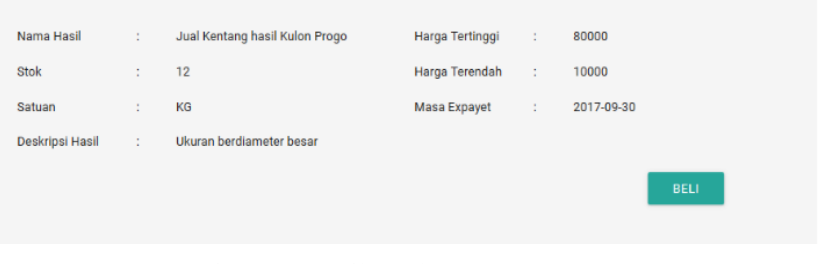

Fig. 16. Detail Product Page.

Figure 16 shows the product information detail. Product information, like unit, price, and product description, highest and lowest price are shown in this page. User is able to see the remaining stock available in this page.

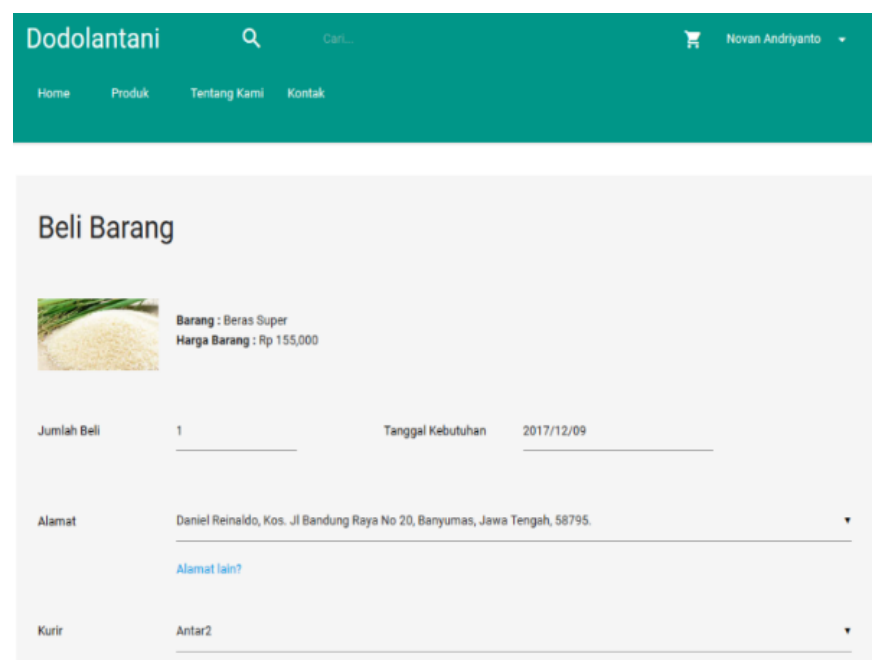

Fig. 17. Shopping Page.

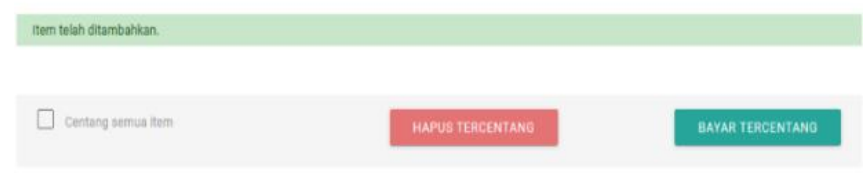

\section{Barang pada Keranjang Belanja Anda}

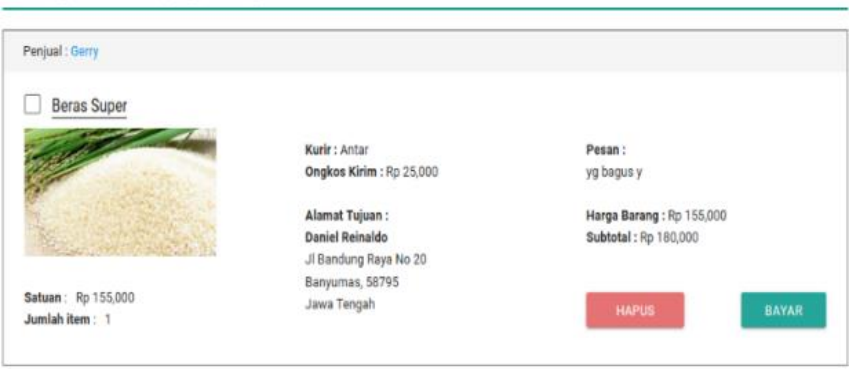

Fig. 18. Shopping Cart Page.
Figure 17 shows the shopping page. In this page, customer should entry quantity of product they eager to buy, requirement date, shipping address, and choose the appropriate courier services. After completing the purchasing process, the product goes to shopping cart. Shopping cart is shown in figure 17 below.

Figure 18 shows the shopping cart page. This page summarizes items that customer buys. Customer is able to delete the item if the customer wants to cancel the order. If customers are ready to pay, customer should press the payment button and the system will bring you to the payment page. Customer should pay via transfer to the stated amount. This ecommerce still has limitation in its payment process. It still has no cooperation with card merchant and banking.

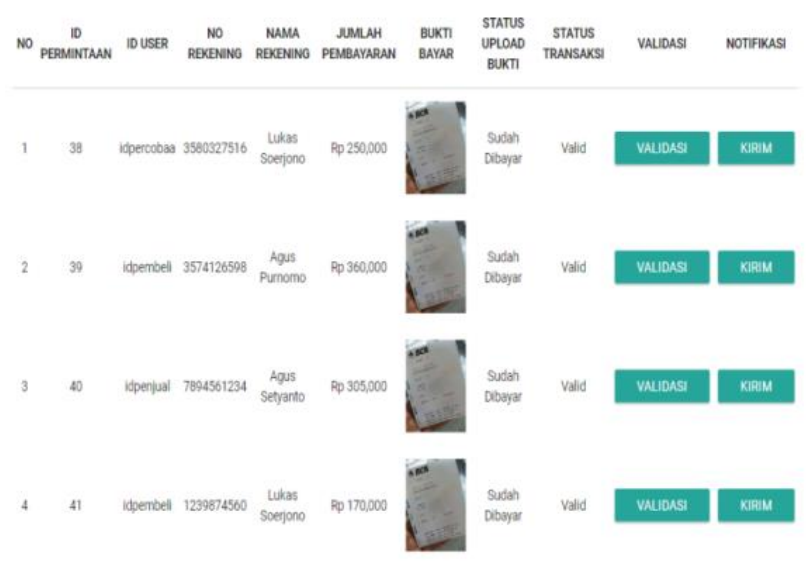

Fig. 19. Payment Validation Page.

After completing the transfer and payment process, customer should upload the transfer receipt. Figure 19 shows the admin validation page. Customer should entry the transfer amount. System administrator will verify the payment process by clicking the validation button. System administrator is also able to send the notification to the seller if the payment has been received.

\section{B. System Testing}

System testing is conducted after the development process finished. System testing is carried out to evaluate and ensure the program is working according to the functions that have been set. Module testing is carried out focusing on functional and system specification. This model is called Black Box. There are four functionalities specifications that is tested: system interface, basic functional system, system handling, and system security. The number of tests and the percentage of success for each test can been seen in table 2 below:

TABLE II. MODULE FunCTIONALITY MAPPING

\begin{tabular}{|l|l|l|l|l|}
\hline No & Testing Specification & $\begin{array}{l}\text { Number of } \\
\text { button or } \\
\text { function }\end{array}$ & $\begin{array}{l}\text { Number } \\
\text { of test }\end{array}$ & $\begin{array}{l}\text { Percentage } \\
\text { of success }\end{array}$ \\
\hline 1. & System Interface & 10 buttons & 61 & 100 \\
\hline 2. & System Basic Function & 3 functions & 40 & 100 \\
\hline 3. & System Form Handle & 3 entry form & 12 & 100 \\
\hline $4 .$. & System Security & 2 cases & 6 & 100 \\
\hline
\end{tabular}


Table II indicates the module functionality mapping results. It shows that percentage of success for the test is $100 \%$. It means that functionality of purchasing module prototype works according to the requirement.

\section{Advantage and Disadvantage Purchasing Module Analysis}

There are some advantages of purchasing module for agriculture e-Commerce: 1) system has been equipped with product discussion. Through this feature, buyer is able to interact and communicate with seller about the product; 2) Information / reports as an output system is able to be saved in pdf format; and 3) this system is web based. It will help the seller to expand the market wider.

There are two disadvantages of purchasing module for agriculture e-Commerce: 1) System is not able to give limitation to product picture size; 2) System does not have product payment feature. It has no cooperation with financial institution.

\section{Dynamic System Development Method (DSDM) \\ Implementation Analysis}

Dynamic System Development Method (DSDM) is implemented to continue the previous study. Two initial phases are feasibility and business study is implemented based on previous study. Functional model and design and build model iteration is implemented, either parallel or sequential. Parallel process is carried out for purchasing and selling module. Otherwise, integration module is conducted sequential after those two modules are successes to be implemented. Implementation of Dynamic System Development Method is suitable and flexible following dynamic changes experienced by the system development team.

\section{CONCLUSION AND FUTURE WORK}

\section{A. Conclusion}

This study concludes that: 1) Dynamic System Development Method (DSDM) is successfully applied by perform two main steps, namely functional model iteration and design and build iteration incrementally. Meanwhile the first two steps, feasibility and business study are done by referring the result of previous research; 2) Purchasing module for agriculture e-Commerce has two main users: purchasing system management and reporting management; and 3) Testing results shows that module prototype runs well in according to defined functions.

\section{B. Future Work}

Future work that is going to be done is integrating purchasing and selling module, system usability testing, and implementation to the farmer community and agriculture industry.

\section{ACKNOWLEDGMENT}

Special thanks to Institute of Research and Community Service Duta Wacana Christian University (DWCU) who give grant to fund our research. Researchers also thanks to Duta Wacana Christian University's Faculty of Information Technology as our base that provides facility in doing this research and has funded the publication of this article.

\section{REFERENCES}

[1] E. Turban, D. King, J. Lee, T. Liang and D. Turban, Electronic Commerce : A Managerial and Social Network Perspective, Cham, Switzerland: Springer International Publishing AG, 2015.

[2] A. G. Khan, "Electronic Commerce: A Study on Benefits and Challenges in an Emerging Economy," Global Journal of Management and Business Research: Beconomics and Commerce, pp. 3-4, 2016.

[3] A. E. Chowdhury, A. Bhowmik, H. Hasan and M. S. Rahim, "Analysis of the Veracities of Industry Used Software Development Life Cycle Methodologies," AIUB Journal of Science and Engineering (AJSE), pp. Vol. 16; Issue 2; June; pp 1-8, 2017.

[4] M. Al-Zewairi, M. Biltawi, W. Etaiwi and A. Shaout, "Agile Software Development Methodologies:," Journal of Computer and Communicat, pp. Vol. 5; pp 74-97, 2017.

[5] J. Stapleton, DSDM Business Focused Development, Second Edition, Great Britain: Addison Wesley, Pearson Education, DSDM Consortium 2003.

[6] K. Slegten, "Dynamic Systems Development Method (DSDM)," 2016.

[7] Agile Business Consortium, "The DSDM Agile Project Framework (2014 Onwards)," 22 Januari 2018. [Online]. Available: https://www.agilebusiness.org/resources/dsdm-handbooks/the-dsdmagile-project-framework-2014-onwards.

[8] B. J. Voigt, "Dynamic System Development Method," Departement of Information Technology University of Zurich, Zurich, 2004.

[9] J. Wang, X. Zhu and C. Zhang, "Models of China's E-Commerce in the Agricultural Sector : an Exploratory Study," International Journal of $U$ ande-Service, Science and Technology, vol. 9. No. 4, pp. pp. 389 - 400, 2016.

[10] J. Huiting, "Discussion on the Construction of Agricultural E-commerce Mode," in International Conference on Ecanomic, Finance and Statistics (ICEFS), Hongkong, 2017.

[11] M. Dong, "International Comparisons on Business model of agriculture ecommerce between India and China," in International Conference on Industrial Economics System and Industrial Security Engineering (IEIS), Sydney, Australia, 2016.

[12] R. Kalpana and N. Shibu, "ICT Usages with E-Commerce in Agricultural Practices," Journal of Commerce and Management Studies, vol. VIII, no. Special Issue 1(2), pp. 63-67, July 2017.

[13] R. Delima, H. B. Santoso and J. Purwadi, "Architecture Vision for Indonesian Integrated Agriculture Information Systems Using TOGAF Framework," in International Conference of Informatics and Computing (ICIC), Lombok; Indonesia, 2016.

[14] H. B. Santoso and R. Delima, "Stakeholder Definition and Analysis for Indonesian Integrated Agricultural Information Systems (IAIS)," in Conference on Information Technology and Digital Application, Yogyakarta, 2016.

[15] R. Delima, H. B. Santoso and J. Purwadi, "Business Architecture Developmnet for Integreted Agriculture Information System (IAIS) using TOGAF Framework," Researchers World, vol. VIII, no. 2(1), pp. pp 0113, April 2017. 